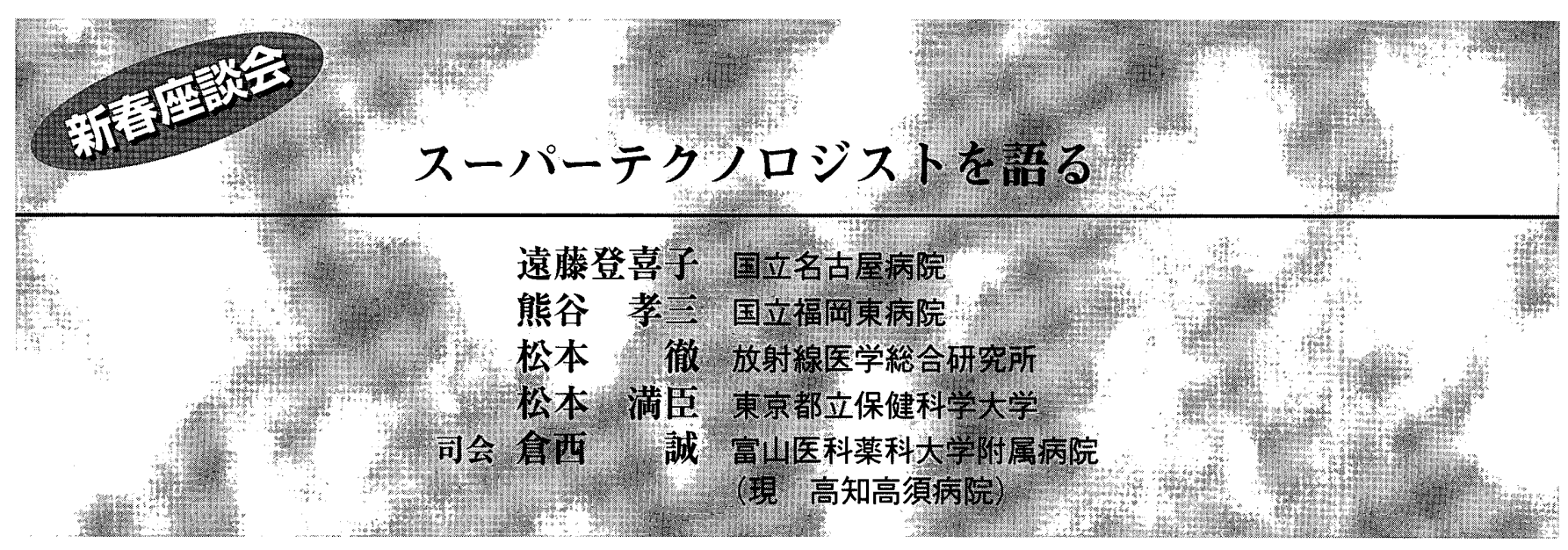

\section{ロスーパーテクノロジスト認定制度 とは}

倉西(以下，KR)：昨年10月に将来 構想特別委員会から日本放射線技 術学会の将来構想答申ということ で, 教育制度変革に伴う本学会の 将来ビジョンが出されました。そ の中の一部で医師の社会では学会 が認定する専門医制度が定着し， 医療のレベルアップに大いに貢献 している。それから医学放射線学 会, 産科婦人科学会, 眼科学会, 整形外科学会, 皮虐科学会, 麻酔 科学会の六つの学会が認定した専 門医を専門性に関する資格とし て，昨年の10月から広告すること ができるようになった。

また放射線科専門医制度の医療 的評価として画像診断 - 読影料加 算が保険的に認められてきまし て, 病院に扮ける放射線科医の存 在価値が高まってきている。

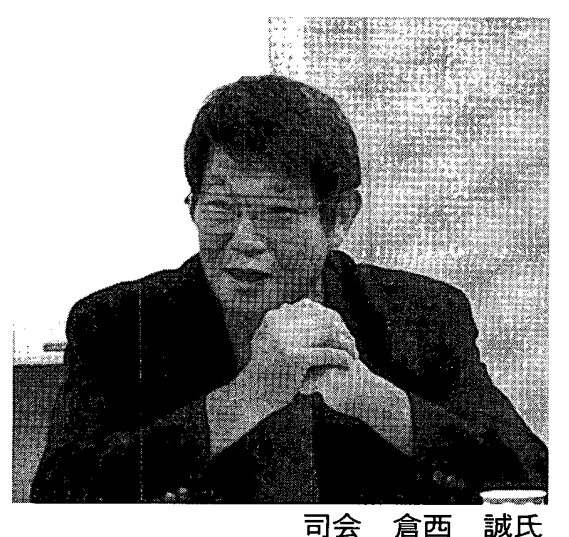

また，放射線技師の教育は 4 年 制に移行してきておりまして，医 療のレベルアップに対応できる放 射線技師の育成の体制が整備され てきている。そういうことを背景 にして放射線技師の専門性の社会 的認知度ですとか職業的存在価值 を高めるということで，本学会が 放射線技師の専門性を認定するス ーパーテクノロジスト認定制度(以 下，認定制度)を設けることが将来 構想答申の中で提案されておりま す.

この提案を受けまして，今年 4 月の総会に扔きまして認定制度検 討特別委員会の設置が承認されま して, 活動を始めて扔ります。

また，同じ答申の中で認定制度 を実現するための課題として，関 連する学会や団体の理解を得ると ともに連携, 協調をとりながら検 討を進める必要がある。それから 専門分野別にスーパーテクノロジ ストを認定するときには，専門分 科会が主導的な役割を果たす必要 がある，そういうことを挙げてお ります。

それで今日はこれらの問題点等 を背景にしながら，お忙しい中， 先生方にお集まりいただきまし た。まずマンモグラフィ検診精度 管理中央委員会のほうから遠藤登 喜子先生, 胸部CT検診の専門技術 者の必要を唱えて扮られる松本徹 先生，日本放射線腫瘍学会の放射
線治療認定技師制度を作られた熊 谷孝三先生, それと, 今, 言いま した本学会の認定制度検討委員会 の松本満臣先生(委員長)に打集ま りいただきまして，本学会が考え る認定制度にとって参考になるお 話を打願いしたいと思います。

司会は私, 企画委員会の倉西が 務めさせていただきます。よろし くお願いいたします。

まず，最初に事の発端となりま した「欧米型」と言っていいのでし ょうか, 松本 (満) 先生, 欧米型の 認定制度について, 先生が将来構 想特別委員会で『Radiology』の論 文, 「The Role of the Supertechnologist」を出されて, 認定制度 導入の議論が本格化した大きな原 動力となったと理解しておりま す。これにつきまして学会誌等で 松本(満)先生には，何度か拈話を 願っておりますけれども，いま一 度，そのへんを扔話し願えればと 思います。

松本 (満) (以下, MM)：将来構想 特別委員会の中で私の役割は教育 制度ということで「その分野を担当 してくれ」と言われました。 それで 以前から今の制度の上に何か新し い，専門性を高めたような仕組み ができないかと考えておりました けれども，たまたま，今，ご紹介 がありましたような論文が 『Radiology』に載りました。

著者のリチャード・フリーデン 
松本満臣(まつもと・みつおみ)

昭和16年島根県益田市生まれ. 昭和 41 年群馬大学医学 部卒後インターン. 昭和42年群馬大学医学部放射線医 学教室. 昭和43年同助手. 昭和48年群馬県立がんセン タ一放射線部. 昭和52年同部長. 昭和63年群馬大学助 教授，医学部附属病院中央放射線部副部長. 平成 6 年東 京都立医療技術短期大学教授，診療放射線学科長. 平成 10年東京都立保健科学大学教授, 放射線学科長. 平成 14年同教務部長. 医学博士，放射線科専門医，日本乳 癌検診学会検診マンモグラフィ読影認定医. がんの画像 診断がライフワーク. 現在, 群馬大学医学部非常勤講 師, 日本放射線技術学会理事, 日本乳癌検診学会理事.

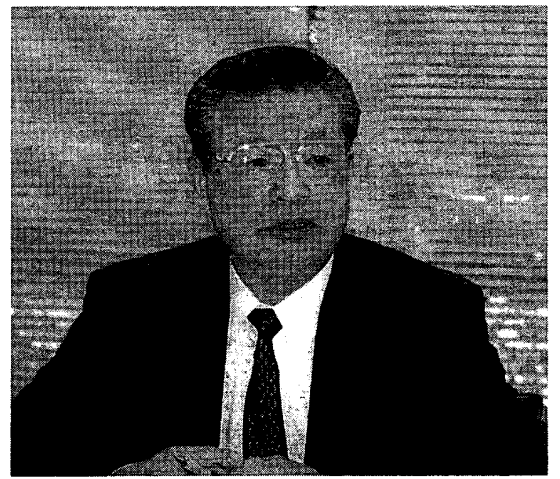

ベルグ先生はカリフォルニア大学 の先生ですが，放射線科医です. 最初のほうをちょっと要約してみ ますと，アメリカではManaged Health Careという医療保険制度が 導入されて; 医療現場でいろいろ な変革が起こってきている：イギ リスでは以前にBritish National Health Care Systemという制度が導 入されたそうですけれども；アメ リカで問題になっているのは医師 の労働時間が増えた。それから医 師の独自の決定権, 裁量権がかな り失われている：そして医師の収 入が減った。そういうことが書い てありまして，「これらは当初, 予 期されたことではなかった」という ことがこの論文の冒頭に書いてあ ります。

そういう変革する医療環境の中 で，一つ，新たな概念として「Skill Mix」，いわゆる「スキルを混ぜ合 いましょう」というのでしょうか, 「技術，腕をミックスしたらどうで しょうか」という概念だと思います が，そういうものが提唱されてき たということです.この「Skill Mix」という言葉は1991年ごろから イギリスで用いられてきたという 背景があるようです。その「Skill Mix」といいますのは「患者さんの ために役立つ専門的な知識とか技 術を補足する, あるいは増大させ るために関連領域のエキスパート を大いに利用したらどうでしょう か」と.「これによって医療におけ る cost savingができるのではない
か」ということを期待しています.

その「Skill Mix」の発端になった 例が紹介されています。これはア シュワスというイギリスの病理学 者ですが，誰が見ても分かるよう な病理標本を高給取りの病理のコ ンサルタントに見てもらうのは, イギリスのNational Health Care Systemの制度の中ではあまりにも 值段が高すぎる．誰が見ても分か るような病理組織標本は適切なト レーニングを受けた技術者に任せ たらどうか.

恐らく日本では臨床検査技師に 相当するのではないかと思います が，したがって，そういうことを すれば病理の医者を増やすという ことではなくて，現在いる有能な スタッフを利用したほうがいいの ではないか：それが医療の全体の cost savingにつながるのではない かという考え方です。

そのように，適切なトレーニン グを受けたテクノロジストによう て，ある程度，医師をアシストす るという業務を行うことで，医師 は労働時間の延長とか煩雑な業務 の一部から解放されていく．そう いうことがこの論文には書かれて 认ます。

「Skill Mix」という言葉そのもの は新しいのかもしれませんが，こ の概念は以前からあったというこ とです。例えばアメリカでは Optician, 眼科の検査を眼科のドク ターに代わって行う資格の人がい たり， Nurse Anesthetistといいまし
て，あまり complicatedでない患者 さんの麻酔を麻酔医に代わってナ 一スがかける。それからさらに は, 最近, 法律がアメリカで変わ って「処方までできるようになっ た」といわれていますが，Nurse Practitioner, それからPhysician Assistantという制度があります。 これらは高校を卒業して 4 年から 6 年の教育コースを出て, 一定の 研修を受けて試験をして，そうい う人達に与えられている資格だと いうわけです。そういうことが紹 介されています。

さらにイギリスではBritish National Health Care Systemが導入さ れてから，放射線科医に迅速な診 断とコスト削減が要求された。主 として経営効率的な理由から医療 サービスの質を落とさずに放射線 技師をいかに利用できるかという ことが，当時，話題になってきた というわけです。そしで10年を経 て，医師が行ってきた業務をいか にトレーニングを受けた技師に任 せられるかという考え方に大きく 変わってきたということが紹介さ れています。

イギリスである実験が行われて います１985年にノースパークホ スピタルという病院の救急部のX 線写真の診断に関する読影実験で す. 診療放射線技師, junior doctor, これが何年目ぐらいのドクターか は分かりませんが，それで読影実 験をやっています。ここに書いて ある内容によりますと, junior doc- 
torは症例の約半数例の異常を見落 としていた。しかし技師はそれら をすべて正しく診断していた。そ ういう報告があります。

これが契機になって，イギリス では異常があると思われるところ のフィルムにマークを付ける，

「Red Dot System」と書いてありま すから，赤い点を付けるのでしょ う.マークする.そういうシステ ムが㕕く行き渡ってきたといわれ ています。

1990年の初めのころに技師が行 つた検査について技師が読影を行 うことに関する研究が始まってい ます.イギリスの 2 人の放射線科 医がかなり先導的な役割を果たし たと記載されていますが，それら について技師が読影を行う場合に 次のような取り決めがなされた。

一つとして「主治医に対しては技 師のレポートであることを明記す る. 主治医は臨床との関連で何か 不可解な点があれば，必ず放射線 科医にコンサルトをしてくださ い」，二つ目は「技師は読影に当た って少しでも疑問があれば必ず放 射線科医にコンサルトする」. 三つ 目は「安全な医療を遂行するため に, 主治医と放射線科医と技師は ガイドラインをつくる」. 四つ目は 「最初のうちは技師の読影を行うに ついては，定期的に放射線科医が その技師の読影をモニターする. 技師がかなりエキスパートになっ てくれば,そのモニターはしなく てもいい. 必ず新しい技師が読影 チームに加わることになる場合に は，このモニター制度を実施しな さい」そそういうことが取り決めら れたというわけです。

そうしましていろいろ書いてあ りますが，1996年にはRoyal College of Radiologist，イギリスの放 射線専門委員会といっていいと思 いますが，そこが技師が読影する ことに了解を与えたというペーパ 一が出されたという内容のことが
$こ の\lceil$ The Role of the Supertechnologist」という論文に書いて あります。

それ以降にわたってイギリスを 初め, アメリカ, カナダでいろん な読影実験をやったことが記載さ れていますけれども，これからの 医療制度を考える中でそういうcomedicalの方々の力を十分に活かす ようにしないと医療のcost saving はできないのではないかというこ とを言っております。

そしてフリーデンベルグ先生は このペーパーを書かれる前にも， 1997年に「次の医学改革はクオリテ イーだ」ということをやはりこの 『Radiology』に書いておられます。 つまり，クオリティーを保ちつ つ，医療費のcost savingをしつ つ, そして適切なトレーニングを 受けた技師さんを十分に活用すれ ばいいのではないか.これが論文 のあらましです.

これを受けまして，日本でも全 く同じものができるとは限りませ んが, 同様のことを検討してもい いのではないか. 逆に, 今, 検討 しないと時代後れになってしまう のではないか. 昭和26年に法律に よって診療放射線技師という職業 が規定されているわけですが，こ れは昭和 23 年の保助看法, つま り, 保健婦 - 助産婦 - 看護婦法に 次ぐ法律で決められた職業的な地 位が確立したわけです。看護では すでに専門看護師制度が導入され ていますし, 診療放射線技師とし てもそろそろこういう専門性を向 上するための仕組みを考えていか なくてはいけないのではないかと いうことで，提案を申し上げまし た。

KR：どjもありがとうございまし た. そういう背景で松本(満)先生 から委員会のほうに提案がありま して，私も陪席で出ていたのです が，それをかなり長時間にわたっ て議論がございまして, 最終的に
「やはり日本でも必要であろう」と いうことで「学会の一つの仕事とし て取り組もう」ということになった わけです。

\section{認定制度への意見と必要性}

KR：いろいろな立場の方のご意見 もお伺いしませんと, 何しろこれ はアメリカなりイギリスでの話な ものですから，わが国にこの制度 を入れるとしましても, 当然, 医 療制度も違いますし社会的な背 景, 思想も大きく違っておりま す.ですから，このへんをどう咀 嚼して, 日本に採り入れるならど うすればいいのかというざっくり したお話です。細かいところまで は行けないと思いますけれども， 今の段階で先生方の個人的なお話 で結構ですので，どういうふうに 思われるか.

いろいろな職業にお就きの先生 に来ていただいておりますので, まず放射線科医という立場で遠藤 先生，いかがお考えでしょうか.

遠藤（以下，E）：欧米式と日本式で は大分バックグラウンドが違いま すので，まさに同じ制度というわ けにはいかないと思います。た だ，医療のレベル，内容について は同じことをしているわけで，そ ういう意味では日本でもチーム医 療という観点, これはもう芽生え ていると思いますし，そういう意 味で放射線科医はチームメイトと して診療放射線技師とナースとは ずっと一緒に仕事をしてきている と私は考えております。

そういうチームを編成しなけれ ば，今の医療，要求されている医 療レベルを達成できない，私自身 はそう考えています。これから議 論が行われると思いますけれど も，診療放射線技師のどういう部 分を専門性として考えていくのか というところを踏まえたうえで は，スーパーテクノロジストの方 向は皆さんの将来を拓くといいま すか, 展望が出てくるシステムで 
遠藤登喜子(えんどう・ときこ)

昭和24年愛知県豊川市生まれ. 昭和48年名古屋大 学医学部卒業; 名古屋掖済会病院で研修後, 内科勤 務. 昭和52年愛知県がんセンタ一病院放射線診断 部, 平成 2 年名古屋大学放射線医学教室勤務. 講 師，助教授を経て，平成 7 年国立名古屋病院放射線 科医長. 名古屋大学医学部臨床教授, 名古屋大学大 学院講師併任. マンモグラフィ検診精度管理中央委 員会委員，同教育・研修委員会委員長として，マン モグラフィおよびマンモグラフィ検診の精度管理を 推進.

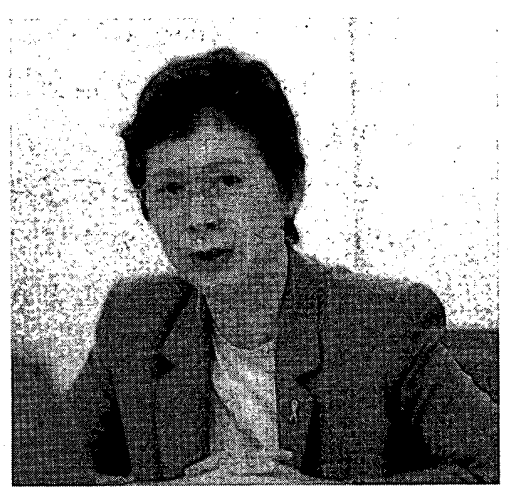

はないかなと考えております。 KR：どうもありがとうございま す。それともう一つ, 今, 放射線 医学の中で大事な位置を占めてき ておられます医学物理士として， 松本徹先生，いかがでしょうか. 松本(徹) (以下，MT)：本日は医学 物理学会を代表してではなくて， 「1 人の医学物理士としての立場か ら」ということで，「気楽に」という ことで参加させていただきしし た.また胸部CT検診研究会の運営 幹事という立場でも話をさせてい ただきます，ただ今，松本(満)先 生のお話を聞いて大変参考になる とともに，CTを導入して肺がん検 診をするというような事業では， 特に医師の業務の一部を専門技師 に担当していただく必要があると いうことを強く感じました。

ただこれを本当に制度化しよう としたら，お医者さんから受け入 れてもらうようにするためいろん なステップを踏まなければいけな いたろうとも思いました。しかし これはぜひそういう方向でやって いくのが時代の流れと思います.

ただしそここに医学物理士がど れくらい関与できるのかはちょっ とよく分からない：と言いますの は医学物理士は国から免許という か，認定を受けた資格ではないの です。あくまでも日本医学放射線 学会からの認定です。しかも登録 人数は現在 140 人ですが, 定年者や 死亡者を差し引くと，現実，125人
なのです．平成14年度医学物理士 試験合格者(認定予定者)48人を加 えても173人にすぎません。

医学物理士が今まで臨床の現場 でかかわってきた仕事のうち，放 射線治療の分野では大変貢献して いると思いますけれども，応用範 囲の広い診断の分野で，しかも国 からの資格でない，人数の少ない ものがどれだけ貢献できるのかは これからの大きな問題です。また スーパーテクノロジストの診療放 射線技師と仕事の分担を今後どう したらいいのか, そのへんを調整 しなければいけなくなるだろうと も思います。

KR：どうもありがとうございま す. あと放射線技師という立場で 熊谷先生, いかがでしょうか.

熊谷 (以下, KM)：私も個人的な意 見ですけれども，放射線治療分野 の放射線技師として捉えていただ きたいと思います。一番問題にな りますのは, 治療現場での放射線
治療技師と医学物理士の関係であ ります，日本と欧米を比較します と，放射線治療システムは全然違 うと思います. 例えば, 一番極端 なことは欧米の物理士は臨床現場 に入り込め，治療現場で仕事を行 っているという事実です。日本の 医学物理士はほとんど治療現場に いません。どちらかといえば，日 本の物理士は大学等の教育・研究 機関の方々が多いわけです.そこ に大きな違いがあります。

日本の放射線治療技師は，当 然, 患者の診療を行っています が，これ以外にも米国の物理士と 同じ仕事を行っています：例え ば，米国の放射線治療の組織をみ てみますと，腫瘍医，看護師，放 射線治療技師，物理士，そのほか 線量測定士，コンピュー夕技師, 補助具やブロックを加工している 製作者，また治療計画で線量分布 計算を行っている方々がいます。 さらに，放射線治療装置等の受入

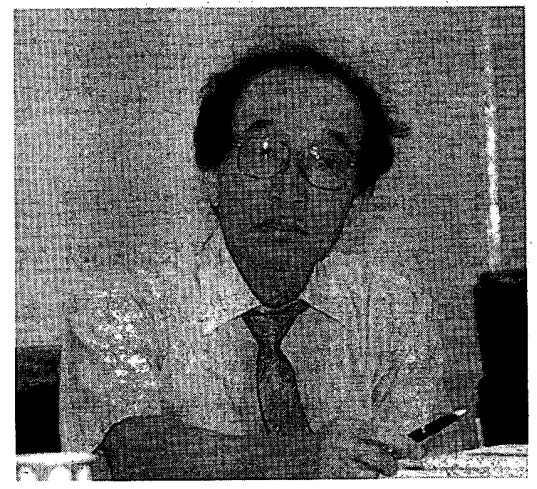

松本 徹(まつもと・とおる)

昭和16年群馬県生まれ．昭和42年 3 月東海 大学工学部原子力工学専攻卒. 同年 4 月科学 技術庁放射線医学総合研究所 (放医研) 入所 臨床研究部研究員, 昭和54年主任研究官, 平成13年独立行政法人放医研医学物理部主 任研究員, 平成14年 3 月定年退職, 平成15 年 4 月放医研医学物理部客員研究員として 現在に至る. 昭和53年医学博士，昭和62年 日医放認定医学物理士, 平成 9 年 4 月 11 年 3 月医学物理士会会長, 平成12年 4 月一 14年 3 月本学会評議員, 現在, 医学物理学 会評議員, 胸部CT検診研究会運営幹事. 
熊谷孝三(くまがい・こうぞう)

昭和24年大分県日田市生まれ. 昭和46年九州大学医学部 附属診療放射線技師学校卒, 平成15年放送大学教養学部 卒. 昭和 47 年国立病院九州がんセンタ一採用, 平成 1 年 国立熊本病院副技師長，平成 4 年国立療養所福岡南病院 技師長，平成 9 年国立病院九州がんセンター技師長，平 成12年長崎医療センター技師長，現在，平成15年国立福 岡東病院技師長. 九州大学大学院工学府エネルギー量子 工学専攻博士後期課程在学中. 日本放射線腫瘍学会評議 員, 認定制度委員会認定技師制度小委員長, （社）日本放 射線技術学会理事, 評議員, 放射線治療分科会長、日本 医学物理学会評議員, 放射線治療研究会代表世話人.

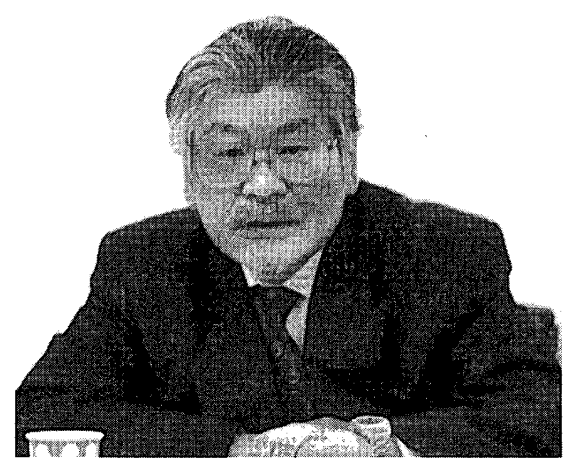

試験，QA・QC，日常の定期点検 を実施している方，それに法的な 問題も多分ありまして，放射線の 漏洩線量などの管理や法令等の申 請を行っている方など多くの職種 があると思います。しかし，わが 国の放射線治療技師は, 米国と比 較して医師と看護師の業務以外の ほとんどの仕事を行っています。

また, 放射線治療制度では, 社会 的, 民族的, 医療保険などの背景 が違う中で，わが国に米国と同じ 放射線治療の組織制度を導入しょ うとしても無理があるわけです。 わが国では，放射線治療現場にお いて, 患者の診療とともに線量測 定やQA・QCの仕事をするのも放 射線治療技師の業務の一つだと思 っています。

後ほど申し上げますが, 日本放 射線腫瘍学会 (JASTRO)の治療技 師認定制度では, 治療現場での放 射線技師の仕事はどういうふうに あるべきかということを述べてい ます．私どもはJASTROの認定制 度をつくるときには, 本当は名称 を「病院物理士」とか「臨床物理士」 という名前にして，「放射線技師で あり，かつ，治療現場でそういう 物理的な内容の仕事も行う資格制 度ですよ」と分かりやすくしようと したのですが, 医学物理学会の立 場からとそれに相当する適切な名 称がなかったものですから，「放射 線治療認定技師」という名前を付け ざるを得なかったのです．現在，
本認定制度はいろんな関連団体と 歩調を合わせて共同認定しません かということを基本に考えていま すので, 技術学会も「ぜひ, 歩み寄 って一緒にやっていただきたい」と 考えています。

\section{口技師教育制度の变革とレベル向 上の必要性}

KR：どうもありがとうございま す．いろんな立場で三つの立場の 先生方に扔話し願いましたけれど も，基本的には，やはりどうして も遠藤先生が最初に扮っしゃいま したように，「今の技師のレベルで は」という問題だろうかと思いま す.

今後，技師のレベルもどんどん 上げなければいかんだろうと思い ますし，そうでなければこういう 専門性, 専門技師というのでしょ うか, スーパーテクノロジストと いうものにはマッチングしていか ないだろうということで，「まず技 師を育てる学校の教育から」という ことがあろうかと思いますけれど も, そのあたり, 学校の教育者と しての立場で松本満臣先生, いか がでしょうか.

MM：これは将来構想特別委員会 のタイトルにもありますように, 「教育制度変革に伴う本学会の将来 ビジョン」という答申になっていま す。ここ過去10年ぐらいの間に大 きく変わってきたのが教育制度で あるわけです。つまり，これまで 3 年制の短大であるとか専門学校
が主体であったものが，4年制の大 学になってきた。 そのリーダー役 を果たしたのは看護学の分野だと 思いますけれども，それに引っ張 られた格好ですべてのco-medicalの 教育が 4 年制大学に変わりつつあ る.さらに 4 年制大学が完成した 以降は修士課程が設けられてきま したし, 博士課程も設置しようと いう動きになっています。

今まで, 残念ながら, 学校教育 法でいう教育の本筋, 本道の部分 から医療系の職種の方の教育はち よっと外れたところにあった。そ れがようやく, 昭和40年代になっ て, 例えば大学附属の看護学校が 医療短期大学部になった。そこで 少し変化した．さらにそのあと医 学部保健学科というふうになっ て，いわゆる学問基盤としてのべ ーズができたという時代に入って きつつあると思います。

そういたしますと，これまでの ような時代ではなくて，この診療 放射線技師の方々がもっと前向き に専門性を高めるというアクショ ンを起こしていいと思いますし， 時代もちょうど“改革の時代”に入 りました。必ず目標を揭げて，そ れにまた評価を受けるという時代 に入りました。

会社であれ病院であれ，あるい は大学であれ, あるいは職種にし ても事務の方々もそうですし，医 師もそうですし，それからcomedicalの方もそうだと思います 
が，すべてそういう評価を受ける 時代に入ってきた。

そういう時代を考えますと，何 かしら目に見えるような改革とい うのでしょうか, 新たなその仕組 みを構築して「われわれも自助努力 をやっております．専門性を高 め, 知識や技術を吸収して高いレ ベルに行こうという努力をしてお ります」ということを世の中の人に 分かってもらえるようなアクショ ンを起こす必要があるだろう。そ ういう気持ちが基本にあります。

医療事情も社会の事情もアメリ カ・ヨーロッパと日本では同じで はありませんから，同じものを追 求してもしょうがないとは思いま すが,やはり学会が中心になって 医学の世界で行ってきた専門医制 度のようなものを，この診療放射 線技師の卒後教育の中にも何とか してっくっていければと考えてい ます。

実は最近，専門医制度に関する いろんな学会の動きが結構出てき まして，例えば外科学会とか内科 学会では, 従来の制度をもう一度 見直して新たな専門医制度を構築 しょうという動きになっておりま すし，記事を持ってきましたが， 『医学界新聞』に外科学会のことが 出ていましたし,「メディカルトリ ビューン』には内科学会のことが出 ています。たまたま，私が当初提 案した「2段階制度」といいます か，.「2 階建方式」といいますか, それを外科学会も内科学会も提案

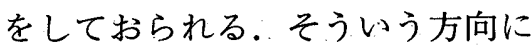
向かいつつあるというわけです。

今，今年からスタートした認定 制度検討委員会で 2 回ばかり会議 を開きまして，その後，さらにメ 一ル等で意見を交換して調整して いこうという段階ですが; この内 科学会も外科学会も基本的には内 科医，外科医としてのベースがあ ります。そういう部分を「1 階」と 称しています。そしてさらに例え
ば循環器とか消化器とか, あるい は神経とか，そういう部分につい てはほかの学会との協力で認定制 度をつくろうという動きになって いるようです。

この記事については最近の朝日 新聞にも紹介されていますが，そ れによりますと胸部外科，心臓血 管外科，血管外科の三つの学会が あるそうですが，これらが合同で 心臓血管外科専門医制度を創設し まして，この秋に最初の試験をす る.そういう方向に決まっている ようです：消化器も同様な方向が 決まっているようですし，小児外 科学会でも外科学会とタイアップ して小児外科の専門医をつくろう としています。

ですから，こういう医学界の動 きもある程度参考にしながら，基 本的には診療放射線技師が国家資 格を取得したのちにある程度のレ ベルに達する部分，これをまず目 指したい，それが 1 階の部分で す.

さらに治療とか診断とか, 診断 の中にもいろいろ範囲はあるかも しれませんが,すでにほかの学会 が認定している超音波検査士もそ うですし，それからがん検診学会 が認定している胃がん専門の放射 線技師の認定制度もそうですし， そういうものといろいろなタイア ップをして，技師の生涯教育の中 での仕組みができていければいい のではないか.

それぞれの専門性の高い部分, ある部分をいわゆる「2 階」に相当 する部分として構築したらどうか という意見を, 認定制度検討委員 会で委員長案ということで提案を させていただいております。こう いうことで来ていますので，委員 会としてまた意見の調整をして， 全体の仕組みがある程度分かるよ うな方向にできるだけ早く持って いきたいと考えております。

KR：どうもありがとうございまし
た. 今の松本 (満) 先生が委員長を されている委員会の中身につきま してはまだ議論中なものですか ら,ここではちょっと控えさせて いただきますけれども；学校の教 育自体がかなり従来と変わってき たという背景もございます。これ につきましては，やはり技師のレ ベルアップが基本的に教育からつ ながってきておりますので，かな りの部分，レベルアップはしてく るだろう。

そういう意味では最初の欧米型 のスーパーテクノロジスト的な制 度を日本へ導入するための基盤は できつつあるのではないか. 私自 身はそう思っております。そのあ たり，何かご意見はございますで しょうか。

特にございませんでしたら，こ の話だけで尽きるわけにはいきま せんので, 私としてはこの話題の 一つのまとめとして，やはりわれ われ，専門職種の集団はどうして も自分達の中に目を向けてしまい がちだというところがございま す.ここで, 松本 (満) 先生のお話 の中で一番大事にしなければなら ないのは, やはり「医療の質を維持 しながら cost savingをするのだ. 社会に対して貢献するのだ」という ことで，これが欧米の認定制度の 根幹の考え方であるということを 忘れてはいけないのではないか. それを忘れて自分達の中に向かっ て考えてしまうというのを若干反 省しながら仕事をしないといけな いのかなと思いながら, 今, お話 を抢伺いしました。

将来構想の中でも一番参考にさ せていただいたのは，やはりわれ われの横に常に扔られる放射線科 の先生方; 言わば放射線科専門医 制度が常にわれわれの念頭にはご ざいました。この委員会にも，残 念ながら括亡くなりになり.ました けれども，愛媛大学の池添教授に も参画いただきまして,いろいろ 
貴重なアドバイスをいただきなが らやらせていただきました。

\section{口放射線科手門医制度の立ち上げ} について

$\mathrm{KR}$ ：そういうことで，今，松本 (満) 先生からもありましたけれど も, やはり医学界で数多くの専門 医制度が設けられて㧍ります。ホ ームページだけを見ましてもとて つもない数の専門医制度を各学会 が扮持ちだという事実があるよう です。日本医学放射線学会には放 射線科専門医という制度がござい ます。

この制度の歴史を伺いながらス 一パーテクノロジスト認定制度を 考えることも役に立つのではない か.やはり歴史的な背景を見なが ら考える必要があるだろう。そう いうことで松本 (満) 先生も遠藤先 生も, 当然, 放射線科専門医とい う立場におられますので，1966年 ですか, 放射線科専門医制度が立 ち上がった。その立ち上げのとき の経緯で何かお話し願えることが あれば，「こういうところを十分考 えて，スーパーテクノロジストは 立ち上げたらいいんだよ」「こうい うエピソードもあるんだよ」という ことで，教えていただけることが ありましたら，お話し願えないで しょうか.

MM：実は，今，扔話のあった放 射線科の専門医制度が立ち上がっ たのが1966年だそうですけれど も，これはまさに私が医学部を卒 業した年なのです。それで放射線 科に勧誘されて入局したわけです けれども，「専門医制度ができるん だって」ということが入局した当時 から話題に上っていました。

同じころに実は麻酔科学会も専 門医制度を立ち上げたのです．当 時, 麻酔科学会と医学放射線学会 の専門医制度の違いで麻酔科学会 から皮肉られました。というの は，日本医学放射線学会ではそれ 相当の経歴, 経験年数, 業績等が
ある方は書類で認定してしまった のです．麻酔科は教授といえども 試験を受けるというシステムから 始まったのです。そその当時, 麻酔 科学会からかなり批判的な目で見 られたということがあります。

医学放射線学会の中でも専門医 制度に対する考え方は決して最初 からまとまっていたわけではあり ませんで，ある大学にいたっては 「あんなの，何の役にも立たない」 ということでかなり反対をされて おられました。しかしながら，い つの間にかこれは定着してしまい ました。その後にほかの学会もこ ういう専門医制度をどんどん採り 入れることになりまして，そうい う意味では麻酔科学会と医学放射 線学会が日本で先陣を切ったこと になると思います，今は医学部を 卒業した医者の卵が専門医制度抜 きには考えられないと思います。 そのぐらい，完全に定着してい る.

私は前にも別なところで申し上 げたことがありますが，医学部を 卒業した人達は一つの目的は専門 医制度でちゃんと認定されるこ と, 二つ目の目的は博士号の学位 をとること, これが二大目標で す. 実は専門医制度の試験を受け るころと博士論文を書くころはほ とんどオーバーラップした時期に なっていまして，30歳ぐらいにな るまでの年齢はやはり物すごく過 密な状況にあります。

しかし，それによってある程度 のレベルの向上ができるようにな って, その結果として先ほど, 冒 頭に司会の企画委員長も扮っしゃ いましたように, 画像診断・読影 加算が診療保険制度の中に設けら れた。これはその点数がいくらと いうことではなくて, 専門医の存 在価値を世の中に知らしめるため に非常に大きな出来事だったとい う感じがいたします。

そういうことから考えますと，
当初, 反対していた大学も今はこ ぞって専門医の試験を受けるとい うことになっていますし，しかも ある年からは 2 段階試験に分けま した。つまり，放射線科医として 診断，治療，核医学に限らず，放 射線の安全管理であるとか放射線 生物学であるとか, そういうもの までも試験科目に含めた 1 次試験 と，それから診断と治療に大きく 二つに分けましたけれども，核医 学が診断の中に入っております が，それが二つ目の試験です．2 段階試験になりました。

こういうことを日本の医学の中 で麻酔科学会と歩調を合わせて比 較的早めに採り入れたのは，今か ら見ると決して間違いではなかっ たと思います。

やはり世の中でそれなりの評価 を受けるためには，新しい仕組み が必要ですし，あとで恐らく話が 出ると思いますけれども，日本乳 癌検診学会がいろんな意味で注目 を浴びていることの一つは，精度 管理中央委員会ができまして，そ の中で医師も技師も認定試験をし ましょう．今日，ご参加いただい ている遠藤先生もその中でいろん な準備のために非常に奔走されま したし，今も大変忙しい立場です けれども，そういうことをやった ことが世の中でそれなりの評価を 受けているのだと思います。です から，いろいろ問題はあるかもし れませんが，ある方向性の中で何 とかこの仕組みをつくりたいとい う感じがしています。

KR：今，ちょっとお話が出ました マンモグラフィの精度管理中央委 員会の件，これにつきましてはあ とで遠藤先生に扮伺いするとし て, 先ほど，立ち上がりの話を遠 藤先生にお伺いするということ で，どうも失礼いたしました。先 生，もっと搭いので，先生が放 射線科に入局されたときに専門医 制度はどういうふうに見られたの 
か，それを教えていただけないで しょうか.

E：私が放射線科医になりました のは大分あとのほうだと思いま す。私の大学では専門医を積極的 には推進してこなかったという空 気がありまして，私自身は大学を 卒業すると同時に：外の病院にい まして，ずっと現場でやってきま した:

専門医制度があるということは 知っていましたし，「専門医をとり なさいりという勧奨もありましたけ れども，実は長いこととっていま せんでした。ただ，大学へ帰局し た段階できちっとした学問をおさ らいするという意味でも；放射線 科学が何であるのか, このあたり をもう一度見直す，学び直すとい う意味で放射線科専門医を受験し ました。

医師になうても専門家としての 修練はその上に立ってあるわけで ございますので，どの科を専門に するにしても，その科における特 殊性，専門性に関して；，一定の期 間, 修練期間があるのは当然です し，またその修練したこと，専門 性について公に示すことによっ て，医療の安全性，そして信頼性 を勝ち得ていけるのではないかと 考えております。

KR：やはり自分の専門性を高める 一つのスキルアップの材料といい ましょうか，そういうことで大事 だろうと思いますし，松本(満) 先 生が扔うしゃったとおり，立ち上 がりはいろいろ紆余曲折があって 大変だうたのだろうと思います。

\section{口医学放射線学会と医学物理士会 の專門医会の関係}

KR：例えば松本(満) 先生のお話の 中にありましたように, 歴史が築 いていくのだ。自分達の努力の中 の歴史が築いていくのだというの が大事だと思いますが，今の制 度, : 専門医会と医学放射線学会の 関係. そのあたりが私にはちょっ
と分からないところがあります し，ひょっとするとわれわれの学 会でも同じような立場の者が出て くるかもしれません.

それでちょっと調べさせていた だきまして，両会のホームページ を見させてもらいますと若干，時 間軸がずれますが，医学放射線学 会の会員数が2002年 7 月で7,320名 と載っております：専門医会のほ うの登録されている先生方の人数 を見ますと，2003年の 4 月で4,217 名という形で出ております。

そうしますと医学放射線学会を 構成されている先生方, 松本徹先 生も多分, 医学放射線学会の会員 なのではないかと思いますが，若 干，医師ばかりが会員ではないと いう特殊性はあると思います。そ れにしてもこの差, 3,000名ぐらい のギャップがございます。われわ れはこのあたりをどのように考え ればいいのか。

医学放射線学会の先生, 放射線 科医の先生が皆，専門医をとられ るのか. 先ほど松本 (満).先生がお っしゃうたように，専門医と博士 号が二つの大きな目標だとする と，3,000名のギャップは若干大き いような気がしたものですから， そのあたり，どう見ればいいの か，ちょっと教えていただければ と思います。

MM：学会はその学問に関心があ って学問を発展させるために会員 を集めていますので，先ほどおっ しゃったと抢り，日本医学放射線 学会も放射線科医だけではない。 内科の先生もいらっしゃいますし 外科の先生もいらっしゃいます し, 場合によっては循環器や脳神 経外科や，そういうところの先生 もいらっしゃいます。

その先生方は自分達の学会で独 自の専門医制度を掞持ちですの で，その方達は放射線の専門医の 資格をとることはまずないだろ う。これが一つあります。
それからもう一つは, 将来, 放 射線科の専門医制度を受験するた めの予備軍.つまり医局に入局し ている． 2 年経てばjuniorの試験を 受けられるわけですけれども，そ してさらにこの 2 次試験を受け て，それでいわゆる認定された専 門医になるわけですが，それまで の方達も含まれている。文う考え れば「まあ,このぐらいになっても いいのかな」という感じがするので すが，どうでしょうか，遠藤先 生.

E：そうですね．専門科が異なる 先生方，これから専門医になって いかれる方; 全く医系ではないけ れども，放射線，医学のほうです けれども，入っていらっしゃる方 もいらっしゃると思うのです：そ れと放射線科の専攻であうても， 医学放射線学会に入っていても専 門医はとらない，またはいまさら とらないという方達もいらっしゃ いますでしょうし，また専門医を 受験されて専門医の資格をお持ち の先生も実は専門医会に入ってい らっしゃらない先生もいらっしゃ るのではないかと思います。

KR：分かりました．特にこの数が 云々ではなしに，そういう場の方 も扔られる。「予備軍的な方」と言 うと失礼な言い方ですけれども， 今から受けようとされる方もかな りおられると理解しておけばいい かと思います。

今，遠藤先生が扔っしゃいまし たように専門医をとりながら専門 医会に扔入りにならない方も扔ら れる。そこで私はもう一つ疑問 は，そこの組織の問題なのです。 医学放射線学会と専門医会は，わ れわれ外野席から見ていますと， 全く別組織に見えるのです。けれ ぞも，いろいろ中身の会則的なも のを見させていただきますと，事 務局とか会費は確かに全く別にな っていますが，例えば専門医会の 内規といいますか，規約等を見ま 
すと，認定試験は学会の認定委員 会がやる，専門医会が拈やりにな るのではなく認定委員会が抒やり になる。しかも「認定する」とか「認 定を取り消す」というのは専門医会 ではなくて学会長がやられると書 かれているのです.

そうすると, 専門医会と学会は どういう立場，どういう関係でお やりになっているのかますます分 からなくなったというのが実態な のですが.

MT : 医学物理士と医学放射線学会 との関係も同じようなことがいえ ます．要するに医学物理士の認定 を受けるのは，医学放射線学会か らです。認定の取り消しもそうで す. 医学物理士は医学物理士会と いう会をつくっています.

放射線科専門医会と医学物理士 会は職能団体であり, 片方は学会 です．学会から認定を受けた者が 自分達の社会的な地位を高めるた めに集まってそれぞれの活動をす る会をつくったのです。もちろ ん，認定していただいたのですか ら, 学会とは切っても切れないの ですが，職能団体は学会と違った ことをしても構わない, 自分達の 利益を最優先した行動をしてもい いのではないか，学会では言えな いことをその専門医会あるいは医 学物理士会でもって発言し行動す る，そういう場所として機能して いると思います。

ただ，医学物理士は現在 125 人が 認定されていますが，医学物理士 会の会員は 100 人なのです. 25 人は 何らかの理由で入っていないので す．100人で圧力団体はちょっと無 理があります。それに比べると医 学放射線学会の放射線科専門医会 は物すごい数の団体です。それが 国を動かして，専門医がいるとこ ろの施設には何かそれなりのもの があるということに結びつけまし た、スーパーテクノロジストの場 合で言えば，そういうことが結局
スーパーテクノロジストの社会的 な地位を上げていく基になるわけ です。

職能団体は，第一に自分達の利 益のために動くのですが，結局， それは学会のためになる，学会が 言いにくいことを言って，学会の 地位も高める，そういう効果があ るのではないでしょうか.

ですから技術学会もス一パーテ クノロジストを立ち上げたら，そ のへんを互いにうまく活用し合っ て共存共栄するような制度に持っ ていったらいいのではないかと思 います。

$E ： 今 ， 「$ 専門医会」という名前で 議論に上っていますが，最近，「放 射線科専門医会・医会」というちょ っと長い名前になりまして，「放射 線科医会」という組織と「専門医会」 とが合併いたしました。そ段階 で「専門医会・医会」は専門医の集 団ばかりではないという職能団体 になってきました。

$\mathrm{KR}$ ：そうなんですか。そこは私， ちょっと勉強不足で申しわけござ いません，今の松本徹先生のお話 も私は理解ができるようなところ があります，というのは，よく聞 きますと厚生労働省は日本の保険 制度に関する諮問を学会ではな く, 全部, 専門医に出しているの です．あそこが全部，返事を出さ れているということで，そういう 意味では社会的な圧力団体といっ てはあれですけれども，社会的な 活動, 一般社会, 学術から離れた 活動を専門医会がおやりになると 理解してよろしいのでしょうか.

MM : その職業に, 医学の場合で すとそれぞれの診療科でしょう か，それに属するいろんな啓蒙運 動とか地位の向上のための運動で あるとか，保険の仕組みの中でも っとその存在価值を認めてもらう であるとか，むしろそういう活動 に力が入っている，それが専門医 会のような会ではないかという感
じですものね.

KR：確かにそういう立場であれ ば，われわれは非常に難しい面も 一つ抱えて扔ります。ちょっと先 生方と違うのはもうすでに職能団 体がわれわれにはあるわけです。 放射線技師会というものがござい ます，そこと技術学会がどう夕イ アップしていくか.これは非常に 難しい問題を抱えておりまして, 恐らく, これは松本 (満) 先生が委 員長として解決されるのではな く, 学会の理事会が組織として考 えなければいけないことだろうと 思っていますが, 専門医会と医学 放射線学会の関係がそういう立場 の関係であることも一つの参考に させていただきながら次のステッ プを考えられるかなと思いまし て, 実は専門医会と学会の関係を ちょっと伺いしてみたわけで す.

それで，大体，私，個人的には 理解できていますし，今，このお 話を読まれる読者の方も少し自分 なりに考えて，分からないところ は, 最近, ホームページに非常に よく丁寧に書かれていますので, ホームページを見ますと学会長さ んの所信表明もきっちり書かれて 抢りますから，そういうものを勉 強しながらやっていただければと 思います。

\section{ロマンモグラフィ検診精度管理中 央委員会について}

$\mathrm{KR}$ ：その次にわれわれの学会で一 番多く占めていますのが放射線技 師になるわけですが，これにつき ましてもかなり先ほど来，いろい ろ，括話が出てきておりますけれ ども, 最近は学会認定の資格が増 えてきております。その中でも一 番関心が高いのが, 先ほど, 㧍話 が出ましたマンモグラフィ検診精 度管理中央委員会. 先生, これは 長いので, 今後,「精中委」と言わ せていただきますが，精中委での 技師の評価制度, それから日本腫 
瘍学会 (JASTRO) での技師認定制 度：もう二つはX線CT検診におけ る専門技師制度，そういうもの が，今，一番，注目を浴びている ところではなかろうかと思ってい ます。

まず最初に精中委の評価制度に ついて，これはもう誰がいうまで もなく；遠藤先生が教育研修委員 長としておつくりになったものだ ろうと思いますけれども，精中委 は乳癌検診学会が中心だと理解を させていただいて：そこへ乳癌学 会とか医学放射線学会, 産科婦人 科学会, 放射線技術学会, 医学物 理学会, 医学放射線物理学会の 7 団体, 医学放射線物理学会が医学 物理学会と合併されましたので, 今は 6 団体だそうですけれども， 乳がんの検診精度向上という一つ の大きな目標があったことは間違 いないと思います。ただ，七つの 団体が立ち上がり足並みを揃える のは大変なことだったのではない かと勝手に想像しますが，遠藤先 生，いかがでしょうか。

$\mathrm{E}$ ：乳がん検診自体を良くしよう という動きは当初からあったわけ です。昭和62年に乳がん検診が発 足して以来, ずっと継続して研究 班がありましたし，また検診学会 も立ち上がったときということ で，それぞれの立場で「乳がん検診 を良くするにはマンモグラフィし かない」という研究活動が行われて きたと思います：

その各学会, 団体の中で活動し ていらっしゃる先生方が「とにかく 目標は一つだ。目標は乳がん死を 減らすことだというシンプルな目 標をつくりまして「そのために違う ことをしてはいけない.同じ基準 で動きましょう」にその一番ベーシ ックな方針を先につくられて持っ ていらっしゃったということだと 思います。

同時並行的に各団体の中で議論 が進んで, その各団体で活動して
いらっしゃる先生方がお互いによ く話ができた，そういう場が研究 班のようなところで提供されてき て，それを統合して報告ができた という背景があるだろうと思いま す、苦労というものでもなかった のではないかと思いますが，やは り苦労はありましたね.

MM：いや，苦労されましたよ。 $E$ ：努力はしましたけれども： $\mathrm{KR}$ ：正直を申し上げまして，今， 松本 (満) 先生も言われましたけれ ども，私もそれなりにいろんな雑 音があったように聞いておりま す. そのへん, 松本 (満) 先生, 何 かご存じのことがありましたら.

MT：こちらの松本がちょっと口を 挟ませていただきます。私も遠藤 先生と一緒にそのマンモグラフィ の検診の発端のところをタッチさ せていただきましので，現・厚 生労働省がん研究助成金遠藤班の 前が大内班で，その前が木戸班で した。その前は富永班でした。私 は富永班の後半から班会議に舘 野, 飯沼先生 (放医研)の同伴者亡 して参加しました。木戸班から大 内班に移るときに，木戸班最後の 会議のあいさつで木戸先生が次の 班を立ち上げる殺し文句ならぬ“活 かし文句”を「考えてくれ」と言われ たとき私は「今後は精度管理をすべ きである」と提案しました。その結 果かどうか知りませんが首尾よく 大内班が立ち上がり，「では，あな たが班員でそれを担当せよ」と言わ れました。私はMMGの専門家では ないので断ろうとしたのですが; 舘野先生から「断るな」と言われ て，それで引き受けたのですが, 困ったのです：そのときは医学物 理関係の学会が二つ(日本医学物理 学会; 日本医学放射線物理学会) あ りましたが, マンモグラフィのこ とを知っている人はほとんどいな かった。

それで，これは技術学会と連携 してやらないと大内班に貢献でき
ないと思い, 私は医学物理学会に MMGを対象としたQA・QC委員会 を提案してつくっていただき，そ れで技術学会と連携して大内班に お手伝いをすることをauthorizeし てもらいました。

そのとき，医学物理士は何も知 らなかったものですから，堀田勝 平先生らに声をかけて，「医学物理 士に何ができますか」と教えを乞い ました. 当時の技術学会撮影分科 会長は小川先生だったと思います が，そのお世話で, 二つの学会か らの関係者で何度か会合を持ちま した。最初は非常にちぐはぐで， 私は間に立って人知れず困ったこ ともありました。それでもがまん して対話を続けていいうちに，互 いに何を分担したらいいかが自然 に分かった感じがしました：結果 的に共存共栄して大内班にも少な

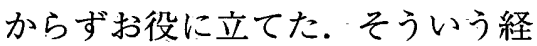
験があります。

ですから，それをスーパーテク ノロジストと結び付けることを考 えると, やはり分野が異なるいろ んな学会の人達と知り合いになる ことがスーパーテクノロジストの 存在を認めさせる一つの方法かな と思うのです。

蛇足のエピソードを追加します と, 外科出身の大内先生は, 私が 「医学物理学会の医学物理士で」と 言ったら，医学物理士の存在を知 らなかったし，私自身は「外科の先 生がなんでマンモグラフィをやる のかな」と思っていました。互いの 分野が交流されて，「あっ，こうい う人達も必要なんだなりということ を枑いに知り合えたということ で，遠藤先生が「苦労はしたが，苦 労ではなかった」と言われました が，私も同感です:

KR : 松本満臣先生, 何か:

MM : この精度管理中央委員会が できるときにも，私は何回か委員 会に出させてもらったことがあり ますが，結局，今，松本徹先生か 
らお話があったように，QA QC, 精度管理はやはり何かあるこ とを進めようとすると一番大事な ポイントたと思うのです。

乳がん検診は一番後発の検診で す.したがって, 今, 世の中の人 の目が医療に対してかなり厳しく なってきていることを考えると， それなりのレベルを確保したとい うことをはっきり示した状態でこ ういう検診が始まらないとだめだ というのが, 恐らく班員の先生と か班長さんの中にあったと思うの です。

したがって研究班としての仕事 が進むと同時に検診学会としても 一緒に，足並みを揃えて進んだ。 今日, 参加していただいている遠 藤先生は医師の読影のいわゆる○ 適マークを認定するかどうかの試 験のシステムをつくるようにとい うことになって, 私も随分お手伝 いをしましたけれども, 2 年, 3 年 かかりましたでしょうか、いろん な施設から症例を集めて国立名古 屋病院に集まりまして，そのマン モグラフィを見て，あの当時は7 人でしたか, 確か 7 人のうち 6 人 まで意見が一致した症例を試験問 題として選ばれたと思います.

マンモグラフィを7 人で見て意 見が分かれた症例は試験をする教 材としてはちょっとまずいという ことで, かなり精選されたので す。その中で試験, 講習をする前 に読影した読影診断率と, それか ら講習会を受けてもう一回同じよ うな症例を，並べ替えてはありま すが, 再読影して診断率を出され まして，教育をすれば間違いなく 診断率は上がるのだというデー夕 を班会議の中で得られました。

これは精度管理中央委員会とし ては卒後教育の中でこういう専門 家を認定するという非常に重要 な, そのべースになるデー夕を得 られた。それがあったものですか ら, その後は比較的, 遠藤先生は
忙しい思いをされていますけれど も, 希望者も多いし, 関連する方 達が意欲を持って参加して資格を とろうとしている。そうなってき ているのではないかという気がし ます。

KR：いろいろお伺いしているとよ く分かります．遠藤先生が最初に おっしゃいましたように，ターゲ ットが「シンプル イズ ベスト」 だということが一番のポイントか なと今，お伺いしました。ただ， 一つお聞きしたいのは, 今，松本 徹先生もおっしゃっていましたけ れども，学会が共通に話せる場, 研究班というものがあった。これ が非常に大きいポイントだったの ではなかろうか. その研究班は一 体どこから誰がどうやって立ち上 げたのだろう。これが今度，一つ の疑問ですが, そのへんはどうで しょうか.

$\mathrm{MM}$ : 富永班の立ち上がりのころ からの話.

$E$ : その「研究班」といっています のは, 当時, 厚生省のがん研究助 成金の研究班のことです，その立 ち上げのところに関して, 私は木 戸先生の下でお手伝いの立場でし たので, 詳しくは分かりませんけ れども，富永先生が「とにかく乳が ん検診を良くしなければいけない」 という方向で,「そういう研究が必 要なのだ」ということを訴えられて 認められたのだと思います。

その研究の内容, 方向性は富永 先生がお考えになられて, 関連す る学問分野の方達に技をかけら れていったと思います。その後は その研究の中で派生してきた関連 事項を解決するためにお声をかけ られて大きくなっていったのだろ うと思います。

$\mathrm{KR}$ : 今の先生のお話を私なりに勝 手に解釈させていただくと，富永 先生という非常に力をお持ちの実 力のあられる先生が抢られて, 強 引ではないでしょうけれども，し
っかりしたリーダシップをとられ て，しかもその先生が幅広くもの を見れる方であったことが，今， この検診が育ってきた大きな一つ の基盤にあるのでしょうか.

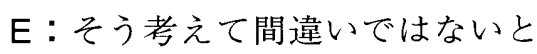
思います。

$\mathrm{MM}$ ：私の記憶が間違いでなけれ ば, 富永班の最大のデー夕は, 視 触診で乳がん検診を受けた群と外 来に来られた患者さんの群では10 年生存率に差がないという報告で す.これがやはり大きいだろうと 思います。つまり，「10年生存率に 差がないのであれば今やっている 視触診による乳がん検診は意味が ないではないか」ということです。

それを受けて木戸班では具体的 に欧米でやっているマンモグラフ イを採り入れるための方策を検討 されたという気がいたしますし， そのころに日本医学放射線学会も 放射線技術学会も一緒になって, 将来のためにマンモグラフィを使 った検診が行われるとしたら，ど ういうことを撮影する側, 装置は 満たさなくてはいけないか, いわ ゆるそのガイドラインをつくられ たということですよね.

そして大内先生になられて, 実 際にマンモグラフィを使って検診 された地域的なデータをかなり詳 細に分析されました. それで50歳 以上についてはその集めた日本の データでも欧米と同じような方向 性が見出せるということになっ て, その結果, 「平成12年からマン モグラフィを使った乳がん検診を 推進しましょう」という厚生省の意 見になったというわけです.

そのあとを受けて遠藤先生が班 長でやられたのは，日本の乳がん のピークは実際にはもう少し若い 年齢にあるものですから，そうし ますとマンモグラフィがやや苦手 とする乳腺組織の多い40代に対し てどういうアプローチをするかと いうことで，遠藤先生はずっとや 
ってこられた。

そういうふうに; 班がいろいる 取り上げたテーマを解決しては次 の方向性を見出して積み重ねてき た.これが大きいのではないかと いう気がします。

KR：どうもありがとうございま す：それで一つ，ちょっと遠藤先 生にお伺いしたいのですが，私の 勉強不足と怒られれば怒っていた だきたいのですが，いろんな専門 医制度とか認定制度がございま す．大概，段階的なものを設けず に一つの制度としてやっておられ るのが普通ではないかと思います けれども，精中委の認定に関しま してはこれはランクをつけると いう意味ではなく「あなたの実力は こうですよ」という $\mathrm{A}, \mathrm{B}, \mathrm{C} と い$ う形がついておりますね。

$E$ : はい.

KR：そのへんを設けられた理由は 何かあるのでしょうか.

$\mathrm{E}$ : 今日の朝日新聞の記事を拝見 させていただきして，私は大変 驚きました：認定自体には私は段 階は設けていないという認識でお ります：あくまでも，読影の力が あれば大きな間違いは起こさない でしょうという一線だけを認定 し，ただし私がしています教育研 修ということになりますと,やは り自分の持っている力, 読影力を 正確に認識していただきたいとい うことがあります。

そういうことで十分な読影力な のか，あるいは非常によく理解を していて教育的な立場にも立てる ぐらい分かっているのか，あるい は「もう少しで到達できますよ」 と. そういう目印をつくることが 大切だうということで，この $\mathrm{A}, \mathrm{B}, \mathrm{C}, \mathrm{D}$ というランクにはつ けておりますけれども，それはや はり自己研修，自己を高める，そ ういうところが大きなものであり ます。

KR：やはりセルフコントロールの
ためのデータであるということ で，別に能力を評価するものでは ないと理解してよろしいのでしょ うか.

$\mathrm{E}$ : その能力は評価していると思 います。ただし，人格を評価して いるわけではないものですから， そこは誤解のないようにと私はい つも願っております。

KR：分かりました。 それからもう 一つ, 先生, 精中委の活動を見て おりますと, 今, マンモグラフィ が, 日本の社会の中で非常に乳が んに関心があるというのも一つの 理由なのかもしれませんが, いろ んなところで社会的な理解を得 る, それから定着させる努力をさ れておられるように思うのです が，どういう点に気をお配りにな りながら，そういう機会をおつく りになっているのでしょうか. E：先ほども申しましたように， この運動自体は目標が絞られてい る運動です。「乳がん死を減らす」 ということです. 乳がん死を減ら すために何が必要かを考えます と, 医療を担っている人達だけの 努力ではあり得ない。医療を担っ ている人と医療を支える人と医療 を受ける人，とにかく皆の問題で あるということだと思います。

検診を推進する立場の者はその 検診の精度を高める努力をしなけ ればならないでしょうけれども， それだけで完結してしまってはい けないということです. 最初にし たことは確かに精度管理, 自分達 のしていることをとにかく精度を 高めて, 良い検診をつくろうとい うところから出発しています.

教育研修委員会の活動として医 師の読影と技師の撮影技術を高め るという方向に最初はあったわけ ですけれども，そのほかにでき上 がりの画像についても，これに対 して本当に良いものかどうか; そ ういうものも評価していかなけれ ばいけないし, 次の課題もまたあ
ると思うのです.そういうものが すべてうまく機能しているかどう か，そういうシステム自体のこと もその精度管理の一つ一番大きな 問題としてまだまだ残ってているだ ろうと思っています。

最終的にはそういう検診を担う 立場からその受診率，要するに目 標に対して必要なものは何かと考 えますと受診率という問題が最終 的には残ってくる。そ部分に関 しても，とにかく情報を提供しな ければいけないのではないか.情 報提供も私達の運動の主体である 私達の仕事だろうと考えるように なっております。

ですから「各方面に対して」とい うご発言，ご紹介でしたが，そう いうことを分かっていただこうと いうことで，すぐ横の人，前の 人，とにかく職種を超えてお話を することによってこの運動が支持 されたと思います。それは目標が 共通して持てるものだったという ことだと思います。

KR：確かに, 今, 先生がおうしゃ ったとおり，われわれの技術学会 の中でも年に 1 回, 2 回, 市民公 開講座という形で乳がんを考える 会がございます。そこで実際の患 者さんになられた方が来られてお 話を聞きますと，やはり臨床現場 にいる人間が考えなければならな い言葉が結構出てくるわけです. ですから；そういうのも一つの大 きな勉強になりますし患者さん自 身も自分が治ろうという気持ちが なければ治りませんし，それから 自分が受診しようという気持ちが なければ乳がんの検診率は上がら ないと思いますし，そういうこと が社会的には非常に大事だろうと 思います。

ずばり，先生にお伺いしたいの ですが，精中委の活動を今まで長 年やってこられまして精中委その ものの先生が活動を評価されると したら，今，どうお考えでしょう 
か.

$\mathrm{E}:$ 精中委の現在の活動を評価す るわけですね.

KR：はい.

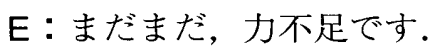

KR：そこまでおやりになって，ま だ力不足?

$\mathrm{E}$ ：はい. 今，やっと基礎固めが できたところだと思います。これ から，医療を担っている人達が， こういう自己研修, 研修が大切で ある, 精度が大切であるというこ とが皆の共同理解となっている段 階でして, そしてその検診の主体 が固まりつつあるという段階であ る.でも, 精中委の活動はこれか らの活動なのです.ですから,こ れからこの主体がいかに活用され ていくのかというところで, 今, 頑張りどころだと思います。

というのは実際の検診, 市町 村, 県, そういうところで検診の 話をさせていただいたりしますけ れども，そういうところではまだ まだ浸透していないわけです．精 中委の存在は大分知られていると いう段階であって, その活動自体 はまだまだできていない。つまり 検診の成果を評価する, 本当に精 度が良いのかどうか, そういう活 動はまだできていないと私は思い ます。

KR：そうすると，今からそれを。

$E ：$ こからです.

$\mathrm{KR}$ ：そうすると, 制度の立ち上げ が終わった段階と考えてよろしい でしょうか.

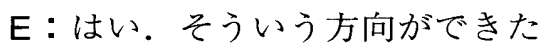
段階にしかないと思います。

KR：われわれ，中から見ています とかなり完成した組織と思ってい たのですが，やはり一般社会に向 けてはまだまだ大きい努力が必要 だと先生は㧍考えなわけですね.

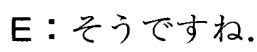

KR：それと精中委のホームページ を見ていまして一番びっくりした のは，よそのホームページにない
言葉が一つございました。今後の 課題というのがいろいろ，あれは 大内先生が扔書きになられたので しょうか, どなたかちょっと失念 しましたが, 今後の課題を幾つか 揭げておられました。

その中に「経費」という問題が, よそにはない言葉なのです。「今 後, この制度を維持していく一番 大きい問題は予算だ」とはっきりお 書きになっております。恐らく認 定制度ができて動き出す段階にな ったら，ひょっとするとわれわれ も同じ問題を抱える可能性が十分 ある．そういうことで先人のお話 としてその予算的な問題とはどう いう経緯的なものがあって, 一番 大きな課題になってくるのか, ち よっと教えていただければと思う のですが.

$E$ ：これは組織の成り立ちの違い があります，学会は学会員によっ て構成される組織ですので, 学会 員はそれぞれ会費を払うわけで す.ですから会員数に応じた予 算, 経費が出てくるわけです.と ころが精中委という組織はそうで はなくて, 学会という団体が代表 を出して構成している組織です。 ですから学会から補助金という形 で支出はされていますが，それは 補助金であって，活動の資金とい う総額から考えますとほんの一部 にしかすぎないわけです.

乳がん検診という検診の中でも その一つにしかすぎない部分での 活動ですけれども, 精度管理をし ていく活動は非常に幅広いわけで す. 教育研修に関しては受講者の 受講料でほとんど賄えるくらいの ボランティア的, 献身的な講師の 先生方, もちろん, その講師の先 生方もボランティア的であっても そこに参加することによって自分 自身がまた高まるということが現 在あるということで, 積極的に参 加していただいていますが，そう いう保障で講習会が各地で開催さ
れているのが現状です．

画像評価，もう一つの委員会に ありますけれども，画像評価のほ うの委員会も当然, 評価料という 権利が生じますので, 線量測定と か画像評価に関して, そういうと ころで受益者負担という形, 自分 達の組織という形で運営がなされ ていると思います.

けれども，その全体の総括をす る精度管理中央委員会のまさに中 央の委員会部分.これの仕事は非 常に大きいのですが，そこを保障 するような財源がないというのが 現状なのです．非常に大きな社会 的な活動をしていますが，それに 対して基盤がないというのが大き なウィークポイントだということ で，NPOとして何とかしていきた いということで活動はしていま す.

KR：ありがとうございました，恐 らく, 私どもの学会でも確かに先 生が扔っしゃるとおり，会費は入 ってくるとは思いますけれども， 会費はそんなに脵らんでいけるも のではございませんので，うちも 恐らくスーパーテクノロジストが できると同じ問題を会費的にも抱 えてくるだろうと思いますけれど も，もちろん，精中委の仕事を私 どもの学会もお手伝いしなければ いけない立場におります。ただ， 私は予算の関係のことを言える立 場ではありませんが, 私どもの学 会自身も理事会で見ていますと会 計状況の悪化が懸念される面もご ざいますので, できる限りのこと はさせてもらうような話は進めさ せていただきたいと思って抢りま す.

\section{口日本放射線腪瑒学会の認定制度} について

$\mathrm{KR}$ ：ちょっとここで次の話題に行 きたいのですが，次が「JASTRO」 と言ったほうが皆さんには通りが いいと思います。日本放射線腫瘍 学会.ここで認定制度を立ち上げ 
られました。これにつきまして， まずこの認定制度を立ち上げよう となさったきっかけ。これについ て熊谷先生, 教えてください.

$\mathrm{KM}$ : この認定制度は最初は認定医 制度から始まったのですが，各施 設の放射線治療のレベルの向上と いうのがその背景にあるのです が，具体的ないきさつは分かりま せん。放射線技師の認定制度につ いてはお答えすることができま す.

学会の認定制度は社会に広く認 められる必要があるのではないか と考えています。そして，その構 築された制度は患者さんに当然メ リットがあり，病院自体とか認定 資格者にもメリットをもたらすこ とが重要であろうと思われます。 言い換えますと，それは診療に有 用であり，病院の医療の質とか経 営にも貢献できなければならない わけです：そして，個人的にも処 遇改善など利益をもたらす制度で なければならないと考えているわ けです，当然，責任と義務が発生 します。

JASTRO認定制度は，昨年の総 会で承認を受けました。本年度(平 成14年10月 1 日)から開始されまし た。認定制度は認定医制度，認定 施設制度，認定技師制度の三位一 体で確立されました。さらに， 今, 認定看護師制度をつくろうと 模索している段階であります。こ の認定技師制度の募集は，本年度 の 8 月31日に締め切られ, 審査さ れました。本年の10月には第 1 回 の認定技師が誕生します。 JASTROの会員数は正確に分かり ませんが，1,500名ぐらいいるだろ うと思います。その中で技師の会 員は450名ぐらいと思います。そし て，認定申請条件を満たしたもの が150名であります，そのうち，約 80名の方が第 1 回目の認定技師に 承認されます。

もともと認定技師制度の話があ
ったのは平成11年 9 月頃だったと 思います，当時の認定制度委員長 の早㴊先生 (久留米大学教授) から この要請がありました.「認定医と 認定施設の認定制度が現在ある が，放射線治療レベルの向上とい う点で認定技師制度が必要だ」とい うことで「ぜひ，考えてくれ」とい うのを強調されたわけでありま す。しかしながら，話のやりとり の中では，「放射線技師の立場から 本当に制度をつくるのがいいの が, それとも不必要なのか, それ を含めて議論して詰めていきたい」 とお答えしたわけです。

なぜ，私にそういう話があった のかというと, 個人的によく知っ ている間柄ということもあります が，技術学会の治療分科会委員で あったということです、いろいろ な意見があったわけですが，放射 線治療分科会委員会で詰め，技術 学会の中で治療に携わる多くの技 師の賛同を得て治療技師認定制度 に踏み出したのがいきさつであり ます。

認定技師制度の目的は，それぞ れの放射線治療施設の放射線治療 技術レべルを向上していくことに あります。そのためには，当然な がらIMRTなどのような高度な放射 線治療技術に円滑に対応できなけ ればなりません：また, 処方線量 に関係する放射線計測や放射線機 器等の品質保証・品質管理を実践 できることが認定技師の役割とし てあります。そういう意味で, 冒 頭に述べましたように，認定技師 は，放射線治療現場における診療 と放射線物理等の業務を担務して いるわけですから，「医学物理士」 ではなく，「病院物理士」と同じ意 味と考えています。これからは， 関連学会等と共同認定の形で歩調 を合わせていきたいと考えていま ఫ.

KR：先生, よろしいですか. 今, 一つ，この治療認定の放射線技師
の立ち上がりの歴史，過程をお伺 いしていますと，われわれの放射 線技術学会の放射線治療分科会と 全く不可分の関係の中で立ち上が ってきた。

KM：そうです.

KR：そういうことを考えますと， これは松本 (満) 先生が今後; 将来 検討委員会の委員長としてどう捉 えられるかはまた別の議論がある とは思いますが，私の目から見ま すと技術学会の一つの制度として も共有化できるのではなかろう か。そういう気がしてお聞きして いましたが，先生; そ皇あたり は.

KM：JASTROの認定技師の委員 は, 技術学会の治療分科会委員と 同じ者で構成されています。そう いう意味で全体の認定制度委員会 では，放射線技師の意見をうまく 伝えることができます、関連学会 間で共同認定を採用する場合に問 題になることは，会員に対する学 会の考え方，学術的なこと，そし て，そのようなレベルが同じベー スにあるかということです.:この 認定制度は，関連学会等の共同認 定を視野に入れてクレジット制度 のカウントを同じにしています。 技術学会だけではありません，物 理学会も技師会もうまく連携をと れる構想のもとにつくったのが, このJASTROの認定技師でありま す。そう心う意味で，技術学会と は共同認定の連携をとるべースは 十分にあると思っています。

\section{口X線CT検診專門技師制度につい}

$\tau$

KR：どうもありがとうございま す。そういうことで治療のほうの 専門技師といいましょうか，それ も立ち上がってきておりますし， それからもう一つ，先ほども申し 上げましたX線CT検診の専門技師 制度についても，今，動きが出始 めたといえばいいのでしょうか， もう動いていると申し上げてよろ 
しいのでしょうか, そのへん，松 本先生がかなり軸になって動かれ ているとお聞きしていますが，松 本徹先生, そのへん, ちょっと教 えていただけますか.

MT：まず胸部CT検診という概念 は日本で発明されたということで す。松本满臣先生もその発端にか かわっている先生ですが, 学術団 体としては胸部CT検診研究会があ ります。あえて学会にしないで研 究会のままでここまで来ました が，2003年 2 月の大会が第10回大 会で, 私が, 医者でないものとし て初めて，その大会長を務めた， そういう段階に来ています。

また，実は「胸部CT検診が有効 だ」という決定的なエビデンスはま だないのです。日本で発明され て, 例えば放医研では私が代表で 科学技術庁 (現独立行政法人放医 研)から予算をいただいて, 産学官 の共同研究を続けてきました。そ の一方で現実にCT検診を事業とし てやる施設まで出てきたというこ とで，かなり発展はしてきており ますが, 決定的 (RCT : Randomized Controlled Trial, 無作為制御 化比較試験) なエビデンスがないの で，まだマンモグラフィの検診の ような段階にはないといえます。

厚生労働省は, 平成11年に鈴木 隆一郎先生を班長として有効性を 評価するための方法論を検討する 研究班を発足させました，それを ベースにして平成13年からはコホ 一トスタディが行われています。 また, それとは別にがん研究助成 金の土屋班, 柿沼班, 金子班がや はり平成13年から始まっていま す.

胸部CT検診研究会に所属してい る先生方は皆, それらの厚生労働 省の研究班のメンバーとほとんど 同じに重なっている，そのような 状況の中でマンモグラフィが検診 の手段として採り入れられたあの 手法をわれわれはお手本に努力し
ている。そういう段階にありま ఫ.

実は鈴木班は「12年ぐらいかけ て，25億円をかければRCTができ る」という提案を厚生労働省に提案 し，担当の扮役人も頑張ってくれ たと聞きましたが，それは結局， 日本では実現しませんでした。

その代わりといってよいか知り ませんが，日本発の胸部CT検診が 日本で良いデータを次々に出して いったら，これまで肺がん検診に 反対していたアメリカが2003年の 7 月からRCTを始め, 2009年にそ の結果が出ることになっていると 聞いております。

ですから現在は「有効だ」という 決定的な証拠がないけれども，わ れわれは今までのデータから「有効 は間違いないだろう」という期待 と, そういう前提の下に実際に人 間ドッグやら一部の地方自治体で CT検診が現実に行われているわけ です.

\section{CT検診はある程度普及もしてき} たし，年間 4 万件以上 (胸部CT検 診研究会平成14年度全国集計)とい う数が実際に行われていますが, やはり精度管理がすごく問題であ る。特に胸部CT検診研究会の全国 集計にデータを上げてこない機関 と, 班会議あるいは研究会に所属 した先生が主導でやるところでは 随分差がありそうだ。しかし，そ の実態はよく分かっていない. 精 度管理もしなければいけないし， 検診というからには数がないと良 い結果が出ないので検診数も増や したい, といいますと, どうして も人手がかかる. 人手が必要とい うことになります。

特に, CT検診の場合は普通, 現 行の方式ですと 1 人, 1 枚の写真 を読めばいいのですが, CTでやり ますと $10 \mathrm{~mm}$ スライスで撮っても 30枚ぐらい撮れてしまう。それを 読影しなければいけないのが最大 の問題です、現行の肺がん検診は
年間700万人が対象です，日本で一 番数の多い検診です。それをす心゙ てCTで置き換えたとすると，(700 万人 $) \times(30$ 枚 $/ 1$ 人 $)$ の写真を読影 しなければいけないのです。そう したら，もう，とてもではない が, 今の医師の数, 日本中の医師 がとりかかってもこれは無理だろ うということです.

それからあともう一つ重要なの は，CTは進化が物すごく速い装置 であるということです。そして応 用範囲が物すごく広い，検診はそ の一部でしかない，検診に特化し た撮影方法が必要です。しかも現 在検診に使われている，CTは旧い 装置から新しい装置まで多種多様 である。一つのCTでも条件がいろ んなふうに変えられる。そういっ た意味で検診のための標準的なCT 撮影条件の決定はマンモグラフィ の撮影よりもずっと難しいと私は 思います。それでもそれを標準化 して精度管理をしなければいけな い. 精度管理の行き届いた撮影を 行い, 莫大な数の読影量をこなせ なければいけない。というような ことから,一番最初に松本 (満) 先 生が言われた「Skill Mix」，この読 影を，CT撮影のところで専門技師 が必要なのは言うまでもありませ んが, 撮った写真の第 1 読影者を スーパーテクノロジストにしても らうようにしたらいかがか，「胸部 CT検診にはCT撮影専門技師とCT 読影専門技師が必要である」と思い ます。

この考えは 4 月のJRC2003のフ オーラム 1 (増田大会長) で発表させ ていただきました。

さらにもう一つ重要なのは, 検 診はいろんな専門分野の方が協力 してでき上がっているシステムな のです。医学，医療，物理，工 学, 技術, 疫学, 経済, 行政, そ うした人達が一つにうまくまとま って行動しないと，検診をして診 断を確定して治療にまで持ってい 
って：アウトカムは「肺がん死亡の 低減」.これはマンモグラフィと同 じです：非常にすうきりしている のですが，最初から終わりまでが 一貫して行われないとそのアウト カムにつながらないわけです.

私はそのへん全体を管理する精 度管理主任者が必要なのではない かと思うのです．現行の肺がん検 診もどの検診もそうですけれど も，折角検診をしても，あとどう なったかのフォローが足りない. それが現状です．そういうことが ないように最初から最後の治療ま で,さらにそのフォローアップま でを担当する，全体に目を通す精 度管理主任者が 1 人必要なのでは ないかと私は思います。

以上の三つの専門を技術学会の スーパーテクノロジストに担当し ていただきますと大変助かると期 待しているところです。

KR：松本満臣先生が委員長です し，たしか：今, 話題が出ました あの今年の増田大会長も松本満臣 先生の委員会の委員になっており ます:そこから出た話ですので, 松本 (満) 先生, そのあたりは十分 認識の中でお仕事をしていただけ るだろうと思いますけれども。

MM：今日は治療の話, マンモグ ラフィの話, それから肺がんのCT 検診の話, いろいろ出ましたけれ ども，診療放射線技師に関連した そのいろんな専門制度はいろんな 領域でできていいと思います。先 ほど，話がありましたけれども， いろんな学会ですでに始まってい るところもありますし，そことの 連携プレーをいかに上手にやる か.これが必要なのです。

したがうて一筋縄ではいかない 可能性もあるし，ひょっとすると 非常にうまくいって，思いのほか 早くできる可能性もあるというこ とでしょう。これから委員会の方 向性が決まってからの放射線技術 学会の役割は非常に大きいのでは
ないかという感じがします。

KR：今，いろいろ長くお話を聞い てまいりましたが, 時間も迫って おりますので最後に入りたいので すが，私自身はどちらかというと 医療情報系の人間でして，例えば 医療情報学会は今年, これは松本 徹先生はご存じだと思いますけれ ども，8月に医療情報技師という ものを設けて認定試験をやりまし た。そこのメンバーに聞きますと 「当初, 精一杯で 1,000 人ぐらいし か受けないだろうと思っていたの が；蓋を開けるとなんと 7,000 名の 受験があった：試験会場も足りな い, 問題も足りない. 大騒ざをし た」ということで, どうも最近, こ ういう資格認定といいましょう か, こういうものがすごくいろん な意味で重要なファクター, 皆さ んがものを見る目が変わってきて いるという如実な例だろうと思い ます。

この7,000名の内訳がなぜ起きた か, 医療情報学会の理事の先生に 聞きますと, どうも今度はメーカ 一さん達が医療の人達と話せる人 間をつくらなければいけないとい う意識の下でこれを始めたという ことで7,000名にも膨れ上がったの だというお話もお聞きしました。 ですから，やはり医療界, 今, ど なたかもおうしゃったように産学 官，まさしく共同体制でなければ できなくなるだろう。

もう一つ，放射線技師の一つの 大きなメイン団体としては, 先ほ ど言いました日本放射線技師会が ございます。今年 5 月にそこから 新しい『新生涯学習システム要網』 が出ております。目的としては学 習意欲，学習目標を分かりやすく するために「アドバンスト放射線技 師」「シニア放射線技師」「マスター 放射線技師」の三つの技師格を設け るのだとホームページ上で書いて おります。

おのおのについては説明, 注釈
が付いて扔りますけれども；私な りの解釈でしゃべると，こういう ものが独り歩きをして違う解釈に なうていくときもありますので， これは技師会のほうのホームペー ジなりを, 技師会の会員でない限 り雑誌は来ないでしょうから， ホ ームページにはこれがしっかり載 つておりますのでホームページを 見ていただくとして，やはり先ほ どからどなたもおっしゃっていま すし，私自身もそう考えています が, 幾つかの学会, 団体が共同し ながらこういう制度をつくってい きませんと，恐らく認定のための 知識・能力, クレジットは共通し ているわけです。けれども，立場 立場でいろいろな認定をつくる と，受ける側はたった 1 人で， 1 人の人が二つも三つも同じような ことで資格認定を受けなければい けない。これが無駄だとは言いま せんが，どうも不合理ではない か. 先ほど熊谷先生もおっしゃっ たように，二重三重に受けるとい う不合理性がございます。こ北を 避けなければいけないというのも 一つの，松本満臣先生の委員会の 中での議論の中にもあったように 記憶しております。

そういうことをどうするか. 私 は一つ, 大学という職場に勤務し ている関係上, 大学間での単位互 換協定が最近出ておりますが，こ ういう制度がこの認定の中にない のか.ちょうと探してみますと意 外や意外, 医師会と各学会の認定 医とがクレジットの互換性を持っ ているのです。これはここに，先 生方にご案内したホームページに 載っております。

文章でちゃんと取り交わしたと ころ，そうでない形の取り交わし のところも幾つかあるそうですけ れども，かなりの数の専門医と医 師会の生涯学習がクレジットの互 換性を持うているというのがござ いました：これが一つ大きな今後 
のわれわれがスーパーテクノロジ ストを考えていくうえでのヒント になるのではないかと思いますけ れども, これについて 4 人の先生 方，忌憚のないご意見を，お一人 ずつ個人的な意見で結構でござい ますおお教えいただければと思い ます，遠藤先生，いかがでしょう か.

\section{技師はスーパーテクノロジスト 認定制度に何を望むか?}

$E: 1$ 人の技師，あるいは 1 人の医 師が複数以上の認定を受けなくて はいけなくなるという不安, これ は確かにあります。放射線科専門 医も日本医学会の認定医の一つで すが， 2 階建以上の部分について は，先ほどおっしゃいましたよう に,すでに多くの学会が認定医と か専門医という名前の制度をつく っていますので, 1 人の人間が幾 つかの認定医資格を持っていると いうことが現状としてあるわけで す.

それが良いのか，それが本当に 意味があるのかということはもち ろん, 一概に良いとも一概に悪い とも言えないと思いますけれど も，技師，技術学会の考えている スーパーテクノロジストの構成に も全く同じ問題が生じてきている し, これからつくる段階ですけれ ども, もう予想されているわけで す.

マンモグラフィの認定, それか らJASTROの認定.これも非常に 臨床に即した一分野に限ったとこ ろで「あなたはそれに十分な知識, あるいは技術があります」という認 定をしているわけです。ところ が，今，ときどき出てくる学会認 定という形でのスーパーテクノロ ジストに関しては，むしろ「もう少 しポジションを高めるため」という ニュアンスが出てきていると思う のです.

そこでその単位認定互換という 話になってきているわけで, 私が
この制度に対してこれからつくっ ていかれる先生に要望したいの は,このスーパーテクノロジスト の持つ意味をはっきりさせるこ と, それが必要ではないかと思い ます．「博士をとりたいということ と専門医をとりたいというのが, 今, 卒業していく医師の二つの目 標である」という話が最初に松本 (満) 先生からございましたけれど も，この診療放射線技師が何を望 んでいるのか，また社会が何を望 んでいるのか.この二つの方向か らこの制度についてクリアにして いっていただきたいと思います。

KR：どうもありがとうございま す.では, 松本徹先生, 何か.

MT : 「具体的にどういう案」と言わ れてもちょっと思いつきません が，まず，現場で臨床を行ってい る技師さんがいろんなこういう認 定がある中で, どれくらい重複し てとる必要があるのか. そんなに たくさんとっても, その病院でそ のすべての認定された仕事をこな すわけにはいかないわけです.

そのへんで, スーパーテクノロ ジストがどんなことをする認定資 格なのかをはっきりさせて, しか もスーパーテクノロジストになれ ば病院の中の地位も向上し, 病院 の利益にもつながって, その一部 が給料にも反映される。そういう 形にならないと定着しないし，そ れを受けてみようという人もあま り出ないのではないかと思いま †.

だから，そういうスーパーテク ノロジストの資格をとれば自分の ためにも病院のためにもなるし， 結果的に世のため, 人のためにな るという意義ある資格だというこ との道筋を技術学会として明確に 示す.これがその前提だと思うの です.

そうしましたら，ほかの資格は とらなくてもスーパーテクノロジ ストをとれば，もう，これでい
い.これでもう自分は満足する。 これに專念する。そういうこと で，認定資格がいっぱい乱立する 中で「この資格は残るけれども，あ とはどんどん消えていく」という， 認定資格そのものが競争という時 代になって，ある専門，うまくい けばその専門のその資格は生き残 るけれども, 要らないものは今言 つたように「社会的な地位にも役立 たない, 病院も儲からない, 自分 の給料も上がらないという資格を とってもしょうがない」ということ で，自然に淘汰されて，残るもの は残る、そういうことになるので はないかと思います。くりかえし になりますが，一番基は技術学会 が「これをとれば得をする。世のた め人のためになる」というのを示す ことだと思います。

$K R:$ 熊谷先生.

$\mathrm{KM}$ : 松本徹先生に関連しまして, JASTROの認定制度は診療保険点 数表に「医師・技師と施設基準」等 の基準がうたわれていますが，そ の中に「放射線治療を専ら担当する 診療放射線技師は治療経験 5 年以 上に限る」と記載されています。こ れで加算点数330点が取れるわけで す.このように，診療保険点数表 に放射線技師の名称がついている のです．病院側からみても，「この 認定技師制度は，これに相当する のか」という評価を受けることにな ります。このような制度が受け入 れられる制度ではないかと思って います。また，放射線技師で診療 保険点数表に名称が出たのは放射 線治療分野が初めてであろうと思 っています.

MT：それは大きいですね.

$\mathrm{KM}$ ：それと先ほど指摘されました が，同じ専門分野であれば関連学 会では歩み寄って一本化したほう が社会的にみても混乱しないし， 技師個人からみても混乱すること はないし，また，施設からみても 納得できると思われます。どこの 
学会でも似たような資格制度を乱 発しているのはよくないと思いま す。ただ;'共同認定には条件があ りまして, その認定制度の骨子や 認定基準がうまく合ってているど うか: そして, レベルや内容, そ してクレジットが一致しているの かを共同認定を行う際には, 今後 詰めていく必要があると思ってい ます.

KR：どうもありがとうございま す. これは松本満臣先生に「委員長 という立場で」というと, かなりお 答えになりづらい立場だと思うの で, 松本満臣先生個人としていか が㧍考えでしょうか。

MM : 非常に貴重な意見をいただ いたと思います。この認定制度に よって自分の給料が上がるかどう か, これが一番難しいような気が いたします，専門医の資格をとっ ても給料に反映されているところ は今は恐らくないだろうと思いま す.だから，その前にあうた「社会 のため」「患者さんのため」「病院の ため」, そういうことでの意味が大 きいのかと思いますが, 恐らく医 療というものの一部を担っている 職種としては，それこそ先ほども お話がありました「乳がん死を減ら す」「肺がん死を減らす」のと同じ で，とにかく医療の質を保ってわ
れわれが医療のために何ができる か。そこが根幹だろうと思いま す。その点でいろんな制度との骨 組み，枠組みかが共通である。レべ ルもちゃんと一定のところを目指 すという内容にすべきなのでしょ うね.

恐らく，日本放射線技術学会と してやろうと思っても，これは一 つの学会だけでできる話ではない と思いますし，逆に今，それぞれ の学会がやうていないところで全 体の枠組みができあがった中で, 「ここは技術学会が担当しなくては いけないというものがあれば，そ れは比較的簡単にできる可能性は あると思います。

ですから, 技師の生涯教育の中で あるべき姿があって,「これは他の 学会と協調してやりましょう。一部 を技術学会が担当しましょう」でも いいと思うし，先ほど言いましたよ うに, 抜け落ちている部分だけを技 術学会がとりあえずスタートさせる やり方もあると思います。

今：まだこの委員会がスタート して間もない時期で, まだ方向性 も見えておりませんけれども，と にかく, 今, 社会が求めているの は, やはりそれぞれの職種の方が それだけの努力をして専門性を高 めて医療の安全と安心の医療のた
めに頑張っていますよということ で，それを分かっていただけるこ とが大事なのではないかという気 がするのです．

だからそのための一つの方策と してこの專門技師制度，あるいは スーパーテクノロジスト認定制度 と言ってもいいかもしれませんけ れども，そういうものが寄与でき ればと思っております。

$\mathrm{KR}$ ：どうもありがとうございま す. 長時間にわたっていろいろお話 を扮伺いいたしました：本来ですと 司会者がここで何らかのまとめをす るべきですが，正直を申し上げまし て,これはこの雑誌を読んだ会員の 読者 1 人 1 人が自分なりのまとめを して；自分自身にかかわってくる問 題という認識の中でやっていただき たいと思いますので，あえてまとめ はいたしません。

先生方の貴重な意見を会員 1 人 1 人が噛みじめて自分の次を考え る，将来を考える．それがこの座 談会の一つの大きなサジェスチョ ンといいましょうか, 皆様に括話 しできる内容として，これで締め 括りたいと思います。どうも長時 間，ありがとうごさいました。今 後ともまたよろしくお願いいたし ます。

(平成 15 年 9 月 5 日収録) 